\title{
A COMPARISON BETWEEN OZONATION AND THERMAL PROCESS IN RELATION TO COW'S MILK ATTRIBUTES WITH EMPHASIS ON PATHOGENS
}

Farida I. Younis ${ }^{1 *}$, Fayed $^{2}$ A.E., El-Batawy ${ }^{2}$ O.I. and El-Sisi ${ }^{1}$ A.S.

1- Dairy Technol. Res. Dept., Food Technol. Res. Institute, Agric. Res. Center, Giza, Egypt

2- Food Sci. Dept., Fac. Agric., Ain Shams Univ., P.O. Box 68, Hadayek Shobra11241, Cairo, Egypt

*Corresponding author: Faridacheese2002@hotmail.com

Received 3 December, 2019

Accepted 2 February, 2020

\section{ABSTRACT}

Effect of different ozonation dozes on some physicochemical and microbiological properties in raw and pathogens inoculated milk samples in comparison with conventional heat treatment with emphasis on pathogens was aimed to be investigated.

Raw cow' milk was divided into eight equal portions, $1^{\text {st }}$ portion was heat treated at $72^{\circ} \mathrm{C}$ for 15 $\mathrm{sec}$ then rapidly chilled to room temperature. Other 7 portions were treated with ascending ozonation times, namely, nil (served as a control), 5, 1015 , 20,25 or 30 min using an ozone generating device from the air at the rate of $400 \mathrm{mg} \mathrm{O}_{3} / \mathrm{h}$. In another experiment, five portions of previously autoclaved skimmed milk (at $115^{\circ} \mathrm{C} / 15 \mathrm{~min}$ ) was separately inoculated with $0.1 \%$ of 24 -h age broth cultured with Staphylococcus aureus ATCC25923, Bacillus cerues ATCC10876, E. coli ATCC25922, S. typhimurium ATCC 14028 or Sh. flexneri ATCC 12022). All inoculated milks were ozonized for nil, 5, 10 15, 20,25 or $30 \mathrm{~min}$ at the same rate and immediately tested for the survival count of the studied pathogenic strains.

The obtained data indicated that, both raw milk treatments studied, namely thermal and ozonation (for more than $5 \mathrm{~min}$ ) lowered significantly counts of total bacteria, yeasts \& molds, Enterobacteriace and psychrotrophic bacteria than those in raw cow' milk. All counts of pathogenic bacteria were less than one cfu/ml after 30 min ozonation., E.coli and $S$.typhimurium counts were less than one after only $20 \mathrm{~min}$ ozonation. No significant differences were detected in all physicochemical properties among all milks treated whether thermally or by ozonation.
As a conclusion, ozonation treatment of raw and pathogenic inoculated milk up to $20 \mathrm{~min}$ at the rate of $400 \mathrm{mg} \mathrm{O}_{3} / \mathrm{h}$ had significantly improved the microbiological quality being able to cause decimal reductions in the milk native flora. Although there has been a marked decrease in the studied pathogenic bacteria as a result of ozonation, this is not enough for assurances, indicating the need for thermal treatment to assure the complete elimination of pathogenic microbes. Additionally, no significant changes were recorded in the physicochemical properties of the ozone treated milk up to 30 $\mathrm{min}$ at the same rate. Thus, these findings feature the bubbles of ozonation as a substitute to diminish the load of microbes in the raw milk, improve quality and increase the milk shelf-life before different processing.

Keywords: Gram positive and negative pathogenes, Enterobacteriace, Psychrotrophic bacteria

\section{INTRODUCTION}

Conventionally, heating is the common procedure applied to control the load of microbes in milk. It is very straightforward and efficient, but may lead to several sensory acceptability and nutritional losses in the resultant product, particularly when heat treatment is implemented in poor quality milk, which possesses a high load of microbes and hence more heating process (temperature degree and/or time) is needed. A substitute method to decrease the load of microbial load of the milk is the use of substances that deactivate microorganisms with no change in milk safety and quality (e.g. peroxide, ozone, and $\mathrm{CO}_{2}$ ). The use of these mate- 
rials may reduce the time and temperature required in the pasteurization of milk due the reduced initial counts of microorganisms in milk. Above all, these materials may setback the production of enzymes by microorganisms during storage before heating treatment and improve the stability of protein in milk during its shelf-life (Pedras et al 2012).

On the other hand, innovative, easy to implement, and rapid technologies are required for the modern food industry to meet the never ending demands of consumers (e.g. fresh and safe readyto-eat products. Ozone was found to be a powerful tool for sanitation and gaining growing interest. The sanitation with ozone may, then, meet the standards of modern food industry. It also may accomplish the regulations of different food safety organizations as well as the consumer acceptability (Kim et al 1999). However, there are over than 3000 installations of waste treatment using ozone across the world (Rice et al 2000). Speaking from the viewpoint of health, ozonation gained popularity in several countries (e.g. New Zealand, Japan, Australia, North America, and several European countries), in varying degrees (Tiwari and Rice, 2012).

Ozonation has several merits that make it a technology to be considered in the food industry; it is the most powerful sanitizer; it decomposes rapidly to oxygen leaving no residues. Low concentrations of ozone are quite enough to be effective (Khadre et al 2001). It acts strongly against extended spectrum of microorganisms, i.e. bacteria, fungi, viruses, protozoa, and bacterial as well as fungal spores (Roushdy et al 2011).

The relative sensitivity of bacteria to ozone is not widely agreed upon and the results in this concern are not inclusive. This may be attributed to different factors like the strain of cultured microorganisms and other related factors including age and density of cultures and the presence of culture media components that require ozone. Also amongst other factors are the method of ozone application (gas bubbles or uniform aqueous solution), the used device and the accuracy of measuring the microbial potency (e.g. single point determinations vs systematic kinetics). The mechanism by which ozone deactivate microorganisms is complicated. That is because ozone attacks several constituents of cells (e.g. unsaturated lipids, proteins, nucleic acids in the cytoplasm, respiratory enzymes in cell membranes, and coat components of spores, e.g. peptidoglycans in cell envelopes, enzymes and, and proteins and peptidoglycan (Khadre et al 2001).

Recently, ozone industries has been developing the concept of continuous disinfection aiming to keep any imported contamination under control at all times hence minimizing its spread to the final product to guarantee the improving overall product quality and customer satisfaction (Brodowska et al 2018).

Ozonation diminished the initial load of different microorganisms (e.g. total count of aerobic mesophiles, yeasts, molds and lactic acid bacteria) by approximately 2 log cycles. Ozonation has no effect on the physicochemical properties of Minas Frescal cheese samples (Cavalcante et al 2013). Therefore, this research aims were assess the effect of different ozone dozes on some chemical and microbiological properties of raw and pathogens inoculated milk samples compared with that heat treated.

\section{MATERIALS AND METHODS}

\section{Materials}

Fresh full cream cow's milk and skimmed milk were obtained from the herd of the dairy cattle at Faculty of Agriculture, Cairo University. Five food borne pathogens were used, including tow Gram positive bacteria, namely Staphylococcus aureus ATCC25923and Bacillus cerues ATCC10876 and three Gram negative bacteria, namely Escherichia coli ATCC25922, Salmonella typhimurium ATCC 14028 and Shigella flexner ATCC 12022. These strains were obtained from Egyptian Microbiology Culture Collection (EMCC) at Microbiological Resources Center (MIRCEN), Faculty of Agriculture, Ain Shams University, Cairo, Egypt.

\section{Experimental procedure}

\subsection{Designing of milk ozonation}

Forty kilograms of raw cow' milks were divided into eight equal portions, $1^{\text {st }}$ portion was heat treated at $72^{\circ} \mathrm{C}$ for $15 \mathrm{sec}$ then rapidly chilled to room temperature $\left(25^{\circ} \mathrm{C}\right)$. Other 7 portions were treated with ascending ozonation times, namely, nil (served as a control), 5, $1015,20,25$ or $30 \mathrm{~min}$ using an ozone generating device from the air (Electric Anion Ozonizer, Healthy Life, Model, AK$102, \mathrm{UK})$ at the rate of $400 \mathrm{mg} \mathrm{O}_{3} / \mathrm{h}$. 

cow's milk attributes with emphasis on pathogens

2.2. Survival screening of some pathogenic strains in milk towards different ozonation dozes

Twenty five kilograms of fresh skim milk were autoclaved at $115^{\circ} \mathrm{C} / 15 \mathrm{~min}$ then chilled to room temperature. Thereafter, the sterilized milk was divided into equal five portions. Tow portions were separately inoculated with $0.1 \%$ of $24-\mathrm{h}$ age broth cultured with Gram positive pathogenic bacterial strain of Staph. aureus or B. cerues. Other three portions were individually inoculated with $0.1 \%$ of 24-h age broth cultured with Gram negative bacterial strain of E. coli, S. typhimurium or Sh. flexneri. All inoculated milk samples were ozonized for nil, $5,1015,20,25$ or $30 \mathrm{~min}$ at the rate of $400 \mathrm{mg}$ $\mathrm{O}_{3} / \mathrm{h}$ and immediately tested for the survival count of studied pathogenic strain.

\section{Analytical methods}

\section{1. physio-chemical analyses}

Dry matter (DM), protein and ash contents were determined according to AOAC (2012). The fat and titratable acidity (TA) contents were determined according to Ling (1963). Lactose content was determined according to the method reported by Lawrence (1968). The milk $\mathrm{pH}$ value was measured electrometrically using a digital $\mathrm{pH}$ meter (Hanna model 8417) at $20^{\circ} \mathrm{C}$ after calibrating with fresh $\mathrm{pH} 4.0$ and 7.0 standard buffers according to the methods of BSI (1989).

\subsection{Microbiological examination}

The total bacterial count (TBC) was enumerated according to Houghtby et al (1993) using Plate Count Agar at $32^{\circ} \mathrm{C}$ for $48 \mathrm{~h}$. Enterobacteriaceae were determined according to Gaya et al (1987) using Violet Red Bile Glucose Agar (VRBGA) at $37^{\circ} \mathrm{C}$ for $24 \mathrm{~h}$. Psychrotrophic bacteria were enumerated according to Marshall, (1992) using Plate Count Agar at $7^{\circ} \mathrm{C}$ for 10 days. Yeasts and Molds were determined using Malt Extract Agar at 25$27^{\circ} \mathrm{C}$ for 4 days as suggested by Harrigan and Mc Cance (1966). Salmonella sp. was enumerated according to standardized procedures for bacteriological examination of food products as described by AOAC (2012) using Xylose Lysine Deoxycholate Agar for $24 \pm 3 \mathrm{~h}$ at $37^{\circ} \mathrm{C}$. Baird Parker Agar was used for determined staphylococci as in Oxoid Manual (1982). The plates were incubated at $37^{\circ} \mathrm{C}$ for 48 h. E.coli was enumerated according to the method described in Nunez et al (1985) using Violet Red Bile Lactose Agar incubated at $44^{\circ} \mathrm{C}$ for 24 h. B. cereus was enumerated according to FDA (2012) on Mannitol Yolk Polymyxin (MYP) Agar fully absorbed before incubating for 24 $\mathrm{h}$ at $30^{\circ} \mathrm{C}$. Shiegilla sp. was enumerated according to standardized procedures for bacteriological examination of food products as described by AOAC (2012) using Xylose Lysine Deoxycholate Agar for $24 \pm 3 h$ at $37^{\circ} \mathrm{C}$.

\subsection{Statistical analysis}

Statistical analysis was performed according to SAS (1990) using General Linear Model (GLM) with main effect of treatments. Duncan's multiple range was used to separate among of three replicates at $P \leq 0.05$.

\section{RESULTS AND DISCUSSION}

1- Microbiological quality of cow's milk in relation to ozonation versus conventional heat treatment

Data given in Table (1) indicated that, both of heat and ozonation treatments led significantly to lower both of total bacterial and yeasts \& molds counts of milk. Milk samples ozonized at the rate of $400 \mathrm{mg} \mathrm{O}_{3} / \mathrm{h}$ for 5 or 10 min contained total bacterial and yeasts \& molds counts higher than those of heat treated one. Non-significant differences were observed either in count of total bacterial or yeasts and molds between heat treated milk sample and those ozonized for $15 \mathrm{~min}$ (Table, 1).

The reduction in cell count of milk as affected by heat treatment may be due to denaturing the enzymes in the bacteria, damaging the bacterium's cell envelope. While, Todar (2012) explained that, ozonation may be lead to proteins and fatty acids of the envelope lose their shape leading to their weakening. Burley (1985) reported that the reduction in cell count in ozone treated cow milk may be due to that the bodies of bacteria are tightly closed by a comparatively solid-cell membrane where the vital processes are restrained through a system of complex enzymes.

Ozone intrudes the metabolism of bacteriumcells, clearly through inhibiting and blocking the action of the enzymatic control system. An appreciated amount of ozone intrudes the cell membrane, leading to the eradication of the bacteria. Similar findings were reported by Metwally et al (2011). 
Surviving of Enterobacteriacae determined by enumeration and listed in Table (1) indicated that, heat treatment $\left(72^{\circ} \mathrm{C}\right.$ for $\left.15 \mathrm{sec}\right)$ or ozonation of milk (for $15,20,25$ or $30 \mathrm{~min}$ at the rate of $400 \mathrm{mg}$ $\mathrm{O}_{3} / \mathrm{h}$ ) caused reductions in Enterobacteriacae count from $2.18 \mathrm{log} \mathrm{cfu} / \mathrm{ml}$ in raw milk to less than one log cfu/ml in heated milk. While, milk ozonation only for 5 or 10 min resulted in reduction of Enterobacteriacae count from 2.18 to 2.00 or $1.50 \mathrm{log}$ $\mathrm{cfu} / \mathrm{ml}$ respectively. The reduction in Enterobacteriacae in ozone treated milk may be due to that oxidation and, hence, the destruction of the cell wall and cytoplasmic membrane by ozone. Primarily, ozone assails glycoproteins and glycolipids of the bacterial cellular membrane, as well as certain amino acids, such as tryptophan. Further, Dosti et al (2005) added also that, ozone may react with the sulfhydryl groups of some enzymes, which lead to impaired cellular activity. Therefore, the resulting shifts in membrane permeability cause cell lysis leading to improvements in quality of milk and increments in shelf life till heating process. Similar facts were recommended by Cavalcante et al (2013) and El-Loly et al (2013).
Regarding Psychrotrophes counts, the results in Table (1) revealed that, no significant differences existed in Psychrotrophes counts between heat treated and ozone treated milk samples for 20 min. Therefore, it could reported that, ozonation of raw milk at the rate of $400 \mathrm{mg} \mathrm{O} / \mathrm{h}$ for $15 \mathrm{~min}$ led to gain a microbiological quality similar to that of heat treated milk at $\left(72^{\circ} \mathrm{C}\right.$ for $\left.15 \mathrm{sec}\right)$. These results are in line with those found by Cavalcante et al (2013) who observed that ozone gas bubbling might be adopted as a milk pre-process aiming at a decrease in microbial count of raw milk; however, this treatment did not lead to dispose of the required milk thermal process. Selma et al (2008) stated also that, gaseous ozone (10000 ppm for $30 \mathrm{~min}$ ) treatment was effective on blanched cantaloupes to diminish mesophilic, psychrotrophic and yeasts \& molds loads. Milk with ozone treatment at the rate of $400 \mathrm{mg} \mathrm{O}_{3} / \mathrm{h}$ for $5 \mathrm{~min}$ had no influence on microbiological quality of raw milk. These results are in coincidence with those of Cavalcante et al (2013) who observed that the ozonation for $5 \mathrm{~min}$ was not capable of reducing the counts of milk microbes.

Table 1. Microbiological situation (log cfu/ml) of cow's milk as affected by alternative conventional heat or ozonation at the rate of $400 \mathrm{mg} \mathrm{O} / \mathrm{h}$ for different times

\begin{tabular}{|c|c|c|c|c|c|c|c|c|}
\hline \multirow{3}{*}{$\begin{array}{l}\text { Microbiological } \\
\text { count (log cfu/ml) }\end{array}$} & \multirow[b]{3}{*}{ Raw } & \multicolumn{7}{|c|}{ Treatment of cow's milk } \\
\hline & & \multirow{2}{*}{$\begin{array}{c}\text { Heat at } \\
\left(72^{\circ} \mathrm{C} / 15 \mathrm{se}\right. \\
\mathrm{c})\end{array}$} & \multicolumn{6}{|c|}{ Ozonation time (min) } \\
\hline & & & 5 & 10 & 15 & 20 & 25 & 30 \\
\hline Total bacteria & $7.22^{\mathrm{a}}$ & $4.32^{d}$ & $6.15^{b}$ & $5.27^{c}$ & $4.12^{\mathrm{d}}$ & $3.45^{\mathrm{e}}$ & $3^{e}$ & $2.40^{f}$ \\
\hline Yeasts \& Molds & $3.11^{\mathrm{a}}$ & $1.05^{d}$ & $2.9 \mathrm{~b}$ & $2.45^{c}$ & $1.11^{d}$ & $1^{d}$ & $0.9^{d}$ & $0.5^{\mathrm{e}}$ \\
\hline Enterobacteriacae & 2.18 & $<1$ & 2.00 & 1.50 & $<1$ & $<1$ & $<1$ & $<1$ \\
\hline Psychrotrophes & $3.15^{\mathrm{a}}$ & $1.60^{\mathrm{e}}$ & $2.9^{a b}$ & $2.71^{b}$ & $2.50^{c}$ & $2.01^{d}$ & $1.8^{\mathrm{e}}$ & $1.17^{f}$ \\
\hline
\end{tabular}

cfu/ml:colony forming unit/millimeter

Means with the same letter at any position did not significantly differ $(p>0.05)$.

\section{2- Screening of different ozonation dozes on survival of some pathogenic strains in milk}

Survival of some pathogens (log cfu/ml) inoculated in sterilized skim milk a $s$ affected by the ozonation time $(\mathrm{min})$ at the rate of $400 \mathrm{mg} \mathrm{O} \mathrm{O}_{3} / \mathrm{h}$ are present in Table (2). The data stated that, all counts of pathogenic bacteria were $<1 \mathrm{cfu} / \mathrm{ml}$ after 30 min ozone treatment. The mechanism by which ozone deactivate microorganisms is complicated. That is because ozone attacks several constituents of cells (e.g. unsaturated lipids, proteins, nucleic acids in the cytoplasm, respiratory enzymes in cell membranes, and coat components of spores (e.g. peptidoglycans in cell envelopes, enzymes and, and proteins and peptidoglycan).In details, E. coli and $S$. typhimurium counts were less than one after 20 min ozone treatment. Although there has been a marked decrease in the studied pathogenic bacteria as a result of ozonation, this is not enough for assurances, indicating the need for thermal treatment at temperature degrees over the range 

cow's milk attributes with emphasis on pathogens

needed for the growth of normal cells leading to progressive loss of bacterial viability to assure the complete eradication of pathogenic microbes and hence food safety. Similar observations were reported by Proudlove (1989), Kim et al (1999), Selma et al (2001), Aydogan and Gurol (2006), Patil et al (2011), Prabakaran et al (2012), Fontes et al (2012), Cavalcante et al (2013). Hye-Jung et al (2014) and Shreya et al (2015).

\section{3- Effect of ozonation on chemical properties of cow's milk}

The statistical analyses revealed that, neither the kind of treatment (whether, thermal or ozonation) nor the ozonation doze led to any significant difference among all physiochemical properties studied. Whereas, the results of Table (3) showed total solids content of various milk samples ranging between $12.55 \%$ (raw milk) and $12.64 \%$. While, fat content showed levels ranging from 3.1 to $3.2 \%$, whilst protein content (TNx6.38) showed variation ranging from 3.2 to $3.4 \%$. Lactose content showed variation ranging from 4.45 to $4.53 \%$, while ash content showed levels ranging from 0.76 to $0.77 \%$. Treatable acidity \% showed variation ranging from 0.17 to $0.18 \%$, while $\mathrm{pH}$ value showed variation ranging from 6.64 to 6.70 .

These findings are in coincidence with those of Cavalcante et al (2013), who declared that the ozonation up to $15 \mathrm{~min}$ did not change the physicochemical criteria in raw milk.

Table 2. Survival of some pathogens $(\log \mathrm{cfu} / \mathrm{ml})$ inoculated in sterilized skim milk as affected by the ozonation time $(\mathrm{min})$ at the rate of $400 \mathrm{mg} \mathrm{O} \mathrm{O}_{3} / \mathrm{h}$

\begin{tabular}{|c|c|c|c|c|c|}
\hline \multirow{2}{*}{$\begin{array}{c}\text { Ozonation time } \\
\text { (min) }\end{array}$} & \multicolumn{5}{|c|}{ Pathogenic strain count (log cfu/ml) } \\
\cline { 2 - 6 } & E. coli & Staph. aureus & $\begin{array}{c}\text { Salmonella } \\
\text { typhimurium }\end{array}$ & B. Cerues & $\begin{array}{c}\text { Shigella } \\
\text { flexneri }\end{array}$ \\
\hline Initial & 8.30 & 8.50 & 8.40 & 8.20 & 7.40 \\
5 & 5.20 & 6.08 & 5.50 & 7.30 & 6.80 \\
10 & 4.70 & 5.30 & 4.40 & 6.60 & 5.18 \\
15 & 3.20 & 3.40 & 3.30 & 5.40 & 4.28 \\
20 & $<1$ & 0.90 & $<1$ & 2.70 & 1.36 \\
25 & $<1$ & $<1$ & $<1$ & $<1$ & 0.90 \\
30 & $<1$ & $<1$ & $<1$ & $<1$ & $<1$ \\
\hline
\end{tabular}

$\mathrm{cfu} / \mathrm{ml}$ : colony forming unit/millimeter

Table 3. Physicochemical properties of cow's milk as affected by conventional heat or ozonation treatment (at the rate of $400 \mathrm{mg} \mathrm{O}_{3} / \mathrm{h}$ for different times)

\begin{tabular}{|c|c|c|c|c|c|c|c|}
\hline \multirow{3}{*}{ Property } & \multirow{3}{*}{ Raw } & \multicolumn{6}{|c|}{ Treatment of cow's milk } \\
\hline & & \multirow{2}{*}{$\begin{array}{c}\text { Heat at } \\
\left(72^{\circ} \mathrm{C} /\right. \\
15 \mathrm{sec})\end{array}$} & \multicolumn{5}{|c|}{ Ozonation time (min) } \\
\hline & & & 10 & 15 & 20 & 25 & 30 \\
\hline Total solids (\%) & $12.55^{\mathrm{a}}$ & $12.64^{\mathrm{a}}$ & $12.65^{\mathrm{a}}$ & $12.70^{\mathrm{a}}$ & $12.58^{\mathrm{a}}$ & $12.60^{\mathrm{a}}$ & $12.65^{\mathrm{a}}$ \\
\hline Fat (\%) & $3.20^{\mathrm{a}}$ & $3.20^{\mathrm{a}}$ & $3.10^{\mathrm{a}}$ & $3.20^{\mathrm{a}}$ & $3.10^{\mathrm{a}}$ & $3.20^{\mathrm{a}}$ & $3.10^{\mathrm{a}}$ \\
\hline $\begin{array}{c}\text { Protein (\%) } \\
(\mathrm{TN} \times 6.38)\end{array}$ & $3.30^{\mathrm{a}}$ & $3.40^{\mathrm{a}}$ & $3.20^{a}$ & $3.20^{\mathrm{a}}$ & $3.30^{\mathrm{a}}$ & $3.20^{\underline{a}}$ & $3.40^{\underline{a}}$ \\
\hline Lactose (\%) & $4.53^{\mathrm{a}}$ & $4.51^{\mathrm{a}}$ & $4.50^{\mathrm{a}}$ & $4.49^{\mathrm{a}}$ & $4.45^{\mathrm{a}}$ & $4.46^{\mathrm{a}}$ & $4.49^{\mathrm{a}}$ \\
\hline Ash (\%) & $0.76^{\mathrm{a}}$ & $0.77^{a}$ & $0.77^{a}$ & $0.77^{a}$ & $0.77^{a}$ & $0.77^{a}$ & $0.77^{a}$ \\
\hline Treatable acidity (\%) & $0.17^{a}$ & $0.17^{a}$ & $0.17^{\underline{a}}$ & $0.17^{a}$ & $0.17^{a}$ & $0.18^{a}$ & $0.18^{a}$ \\
\hline $\mathrm{pH}$ value & $6.64^{\mathrm{a}}$ & $6.64^{\mathrm{a}}$ & $6.66^{\mathrm{a}}$ & $6.65^{\mathrm{a}}$ & $6.66^{\mathrm{a}}$ & $6.68^{\mathrm{a}}$ & $6.70^{\mathrm{a}}$ \\
\hline
\end{tabular}

TN: Total nitrogen

Means with the same letter at any position did not significantly differ $(p>0.05)$. 


\section{CONCLUSION}

Ozonation treatment of raw and pathogenic inoculated milk up to $20 \mathrm{~min}$ at the rate of $400 \mathrm{mg}$ $\mathrm{O}_{3} / \mathrm{h}$ had a significantly improving effect on the microbiological quality being able to cause decimal reductions in the milk native flora. Although there has been a marked decrease in the studied pathogenic bacteria as a result of ozonation, this is not enough for food safety assurances, indicating the need for thermal treatment at temperature degrees over the range needed for the growth of normal cells resulting in continuous loss of the ability of bacterial viability to ensure the complete elimination of pathogenic microbes. Additionally, no significant changes were recorded in the physicochemical properties of the ozone treated milk for $30 \mathrm{~min}$ at the same rate. Thus, these findings marks the bubbles of ozone as an substitute to diminish of the load of microbes in raw milk, improve quality and increase the milk shelf-life before different processing.

\section{REFRENCECS}

AOAC 2012. Association of Official Analytical Chemists. Official methods of analysis of AOAC International, $19^{\text {th }}$ ed., Benjamin Franklin, Washington D.C., USA.

Aydogan A. and Gurol M.D. 2006. Application of gaseous ozone for inactivation of Bacillus subtilis spores. J. Air \& Waste Manage. Assoc., 56, 179-185.

Brodowska A.J., Nowak A. and Śmigielski K. 2018. Ozone in the food industry: Principles of ozone treatment, mechanisms of action, and applications: An overview. J. Cri. Rev. Food Sci. Nutr., 58, 2176-2201.

BSI 1990. British Standards Institution. Testing aggregates. General requirements for apparatus and calibration. BS 812: Part 100, BSI, London, UK.

Gurley B. 1985. "Ozone, Pharmaceutical Sterilant of the future". Dept. of Pharmaceutics, Univ. of Tennessee, Memphis, Tennessee, pp. 256261.

Cavalcante D.A., Leite Júnior B.R.C., Tribst A.A.L. and Cristianini M. 2013. Improvement of the raw milk microbiological quality by ozone treatment. Int. J. Food Res., 20, 2017-2021.

Dosti B., Guzel-Seydim Z. and Greene A.K. 2005. Effectiveness of ozone, heat and chlorine for destroying common food spoilage bacteria in synthetic media and biofilms. Int. J. Dairy Technol. 58, 19-24.
El-Loly M.M., Mansour A.I.A. and Ahmed R.O. 2013. Evaluation of raw milk for common commercial additives and heat treatments. Int. J. Food Safety, 15, 7-10.

FDA 2012. Bad bug book: Foodborne pathogenic microorganisms and natural toxins handbook, 2nd ed. US Food and Drug Administration, Silver Spring, pp. 93-96.

Fontes B., Heimbecker A.M.C., de Souza Brito G., Costa S.F., van der Heijden I.M., Levin A.S. and Rasslan S. 2012. Effect of low-dose gaseous ozone on pathogenic bacteria. BMC Infectious Diseases, 12, 358-364.

Gaya P., Medina M. and Nunez M. 1987. Enterobacteriaceae, coliforms, faecal coliforms and salmonellas in raw ewe's milk. J. Appl. Bacteriol., 62, 321-326.

Harrigan W.F. and McCance M.E. 1966. Laboratory Methods in Microbiology. Academic Press, New York, USA, pp. 199-228.

Houghtby G.A., Maturin L.J. and Koenig E.K. 1993. Microbial count methods. In: Standard Methods for the Examination of Dairy Products. Marshall R.T. (Ed.), Amer. Public Health Assoc., Washington, USA, pp. 213-246.

Hye-Jung S., Kwang-Pyo Kim W.S., Ryu S. and Kang D. 2014. Combination effect of ozone and heat treatments for the inactivation of Escherichia coli 0157:H7, Salmonella Typhimurium, and Listeria monocytogenes in apple juice. Int. J. Food Microbiol., 171, 147-153.

Khadre M.A., Yousef A.E. and Kim J.G. 2001. Microbiological aspects of ozone applications in food: A review. J. Food Sci., 66, 1242-1251.

Kim J.G., Yousef A.E. and Dave S. 1999. Application of Ozone for Enhancing the Microbiological. J. Food Prot., 62, 1071-1087.

Lawrence A.J. 1968. The determination of lactose in milk products. Aust. J. Dairy Technol., 23, 103-106.

Ling E.R. 1963. A Text Book Dairy Chemistry Vol. 2. practical $3^{\text {rd }}$ ed. Chapman and Hall. Ltd London, UK, pp. 76-98.

Marshall R.T. 1992. Standard Methods for the Examination of Dairy Products. $16^{\text {th }}$ ed. Amer. Publ. Health Assoc., Washington, USA.

Metwally A.M.M., Dabiza N.M.A., El-Kholy W.I. and Sadek Z.I. 2011. The effect of boiling on milk microbial contents and quality. J. Amer. Sci., 7, 110-114. 

cow's milk attributes with emphasis on pathogens

Nunez M., Gaya P. and Medina M. 1985. Influence of manufacturing and ripening conditions on the survival of Enterobacteriaceae in Manchego cheese. J. Dairy Sci., 68, 794-800.

Oxoid $^{\circledR}$ 1982. The oxoid manual of culture media ingredients and other laboratory services. $5^{\text {th }}$ ed. Oxoid Limited, Hampshire, UK.

Patil S., Valdramidisb V.P., Karatzas K.A.G., Cullen P.J. and Bourke P. 2011. Assessing the mechanism of microbial inactivation during ozone processing. Articles School of Food Science and Environmental Health. Technological University Dublin, pp. 1-6.

Pedras M.M., Pinho C.R.G., Tribst A.A.L., Franchi M.A. and Cristianini M. 2012. The effect of high pressure homogenization on microorganisms in milk. Int. Food Res. J., 19, 1-5.

Prabakaran M.T.S., Merinal S. and Panneerselvam A. 2012. Effect of ozonation on pathogenic bacteria. Advances in Appl. Sci. Res., 3, 299-302.

Proudlove R.K. 1989. Dairy products. In: "The Science and Technology of Foods", $2^{\text {nd }}$ ed., Forbers Publ. Limited London, UK. pp. 106107.

Rice R.G., Overbeck P. and Larson K.A. 2000. Costs of ozone in small drinking water systems. Proc. Small Drinking Water and Wastewater Systems. Ann. Arbor, MI: NSF International. pp. 27-36.
Roushdy M.M., Abdel-Shakour E.H. and AbdelGhany T.M. 2011. Sporicidal effect of ozone on fungal and bacterial spores in water disinfection. J. Amer. Sci., 7, 942-948.

SAS 1990. Statistical Analysis System. SAS user's guide. Statistics. SAS Inst. Inc. $4^{\text {th }}$ ed., Cary, NC, USA.

Selma M.V., Ibáñez A.M., Cantwell M. and Suslow T. 2008. Reduction by gaseous ozone of Salmonella and microbial flora associated with fresh-cut cantaloupe. Food Microbiol., 25, 558-565.

Shreya W., Maker J.K., Thompson J.R., Barnes J. and Singleton I. 2015. Effect of ozone treatment on inactivation of Escherichia coli and Listeria sp. Agric., 5, 155-169.

Tiwari B.K. and Rice R.G. 2012. Regulatory and legislative issues In Ozone in "Food Processing”. O’Donnell C., Tiwari B.K., Cullen P.J. and Rice R.G. (eds.). Oxford, WileyBlackwell, pp. 7-17.

Todar K. 2012. "The normal bacterial flora of humans", in Todar's Online Textbook of Bacteriology. Madison, WI: Kenneth Todar. Available at:

www.textbookofbacteriology.net/ (accessed 26 May 2014) 


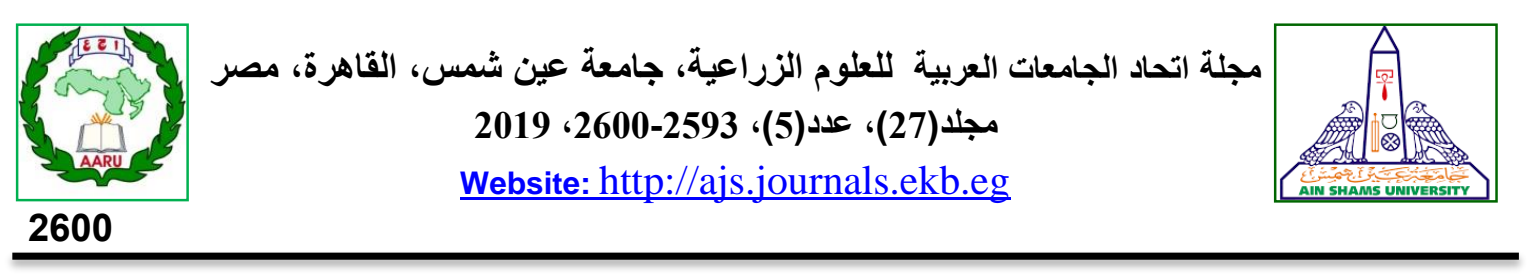

مقارنة بين المعاملة بالأوزون والمعاملة الحرارية وعلاقاتها بخواص اللبن البقري

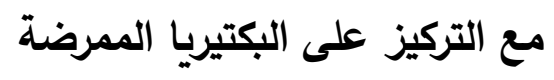

[206]

\author{
فريدة إبراهيم يونس 1" - عاطف السيد فايد2 - أسامة إبراهيم البطاوي2 - أحمد صابر السيسي1 1

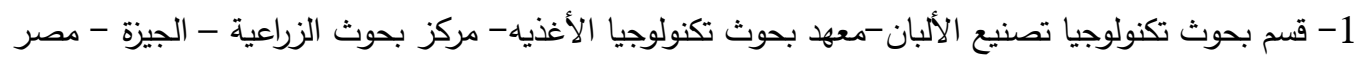

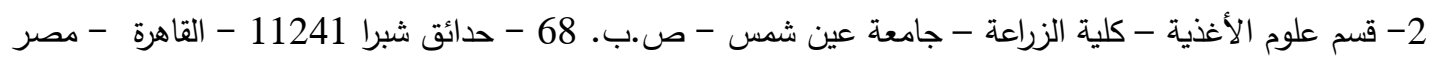

*Corresponding author: Faridacheese2002@hotmail.com

Received 3 December, 2019

Accepted 2 February, 2020

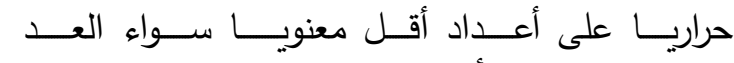

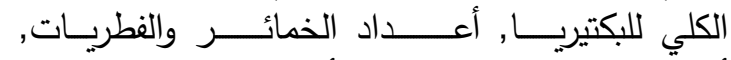

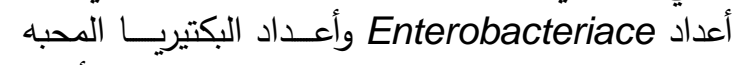

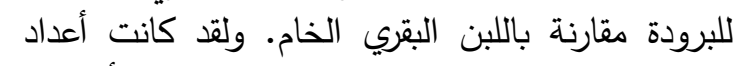

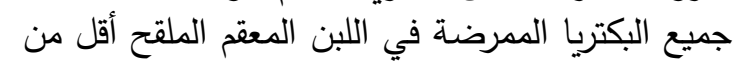

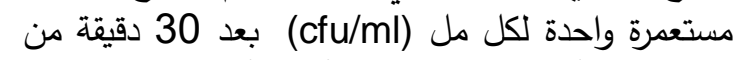

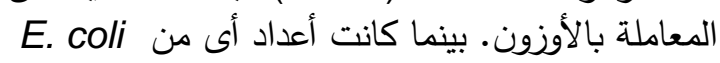

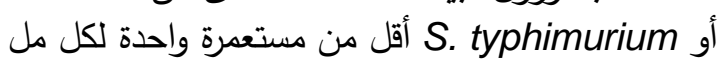

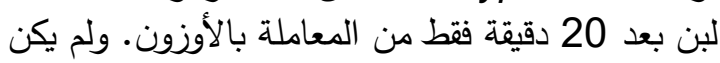
هناك أي إختلافات معنوية في الخواص الفئل الفيزيوكميائية

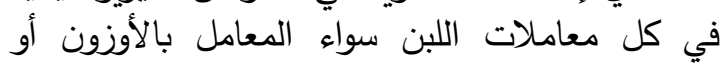
المعامل حراريا. أخيرا يمكن استتتاج أن معاملة اللبن الخام أو اللبن

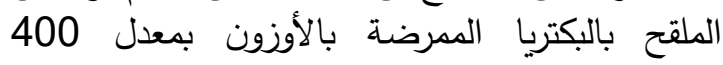

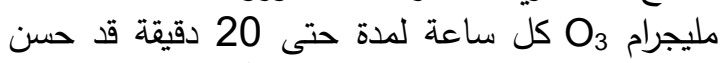

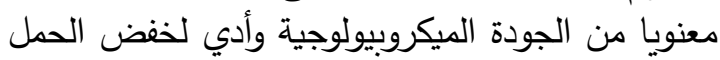

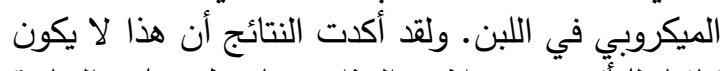

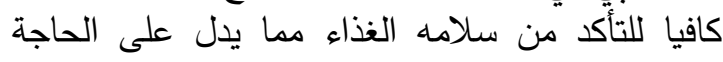

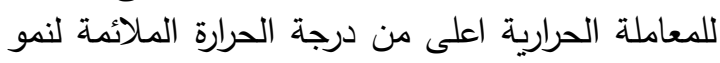

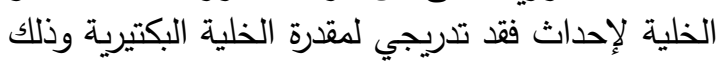

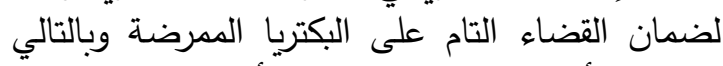

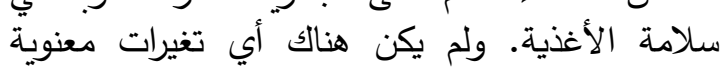

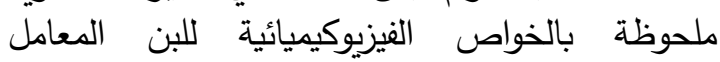
بالأوزون حتى 30 دقيقة.

الكلمات الدالة: الميكروبات المرضيه الموجبه والسالبه لجرام، Enterobacteriace، البكتيريا المحبه للبروده

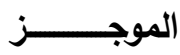

استهدف البحث دراسة تأثير إستخدام الأوزون على لى الفئي

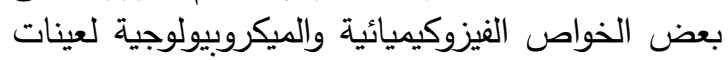

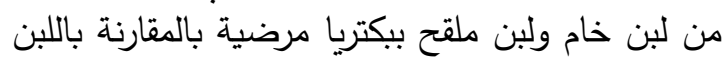

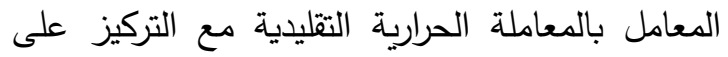

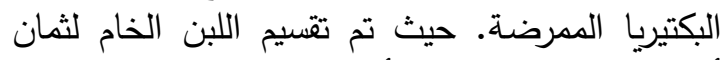

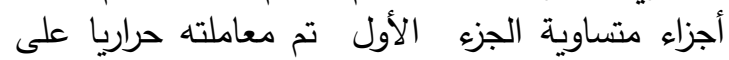
72 72م لمدة 15 ثانية ثم تم تبريده لدرجة حرارة الغرفة.

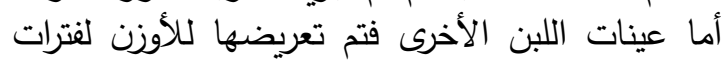

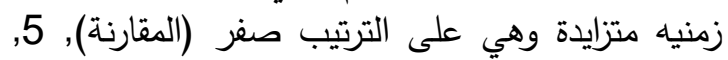

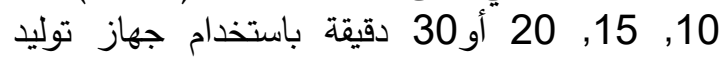

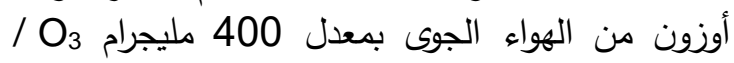
Electric Anion Ozonizer (Healthy ماعرم .Life, Model, AK-102, UK) وفى تجربة أخرى تم تقليح خمس أجزاء من لبن

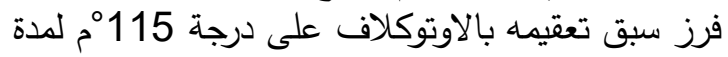
15 دقيقة ثم بواسطة 19 بالاوكلة من مزرعة سائلة عمرها 24 ساعة لأحد السلالات المراسة

Staphylococcus aureus, Bacillus cerues, Escherichia coli, Salmonella typhimurium or Shigella flexneri).

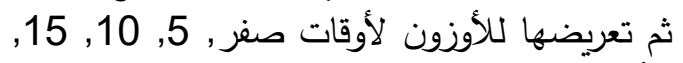

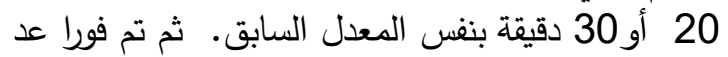

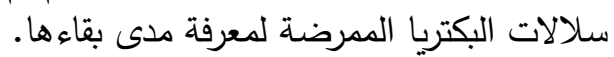
وقد اظهرت النتائج أن، احتواء كلا من النداء اللبن الخدام المعامل بالأوزون (لمدة أكثر من 5 دقائق) والمعامل اللين الخام

$$
\text { تحكيم: ا.د رزق عزب عواد }
$$

